\title{
EFEKTIVITAS OBAT KUMUR EKSTRAK ETANOL DAUN BELUNTAS (Pluchea indica L. ) UNTUK MENGATASI HALITOSIS PADA REMAJA
}

\author{
Ni Nengah Sumerti ${ }^{1}$, Regina Tedjasulaksana ${ }^{2}$ \\ Maria Martina Nahak ${ }^{3}$ \\ *Dosen Politeknik Kesehatan Kemenkes Denpasar
}

\begin{abstract}
Known as bad breath, halitosis also called oral malodor is a bad breath that comes from air expelled by a person through the mouth. Halitosis is caused by local and systemic factors, but $90 \%$ of patients with halitosis due to local factors in the oral cavity, including at adolescents. The purpose of this study was to determine the effectiveness of mouthwashes of ethanol extract of leaves beluntas to overcome halitosis. This is an experimental research with completely randomized with prepost control group design. Samples are adolescents junior high school students. Data were analyzed by Wilcoxon test, Results shown that there is a significance difference before and after rinsing in the groups and Friedman test shown that there is the significance difference between groups. The results of the study shown that mean average of mouth rinsing with ethanol extract of beluntas leaves with $12.5 \%$ in concentration is $0.167 \pm 0.408$, with $p=0.038$ or $p<0.05$, rinsing with ethanol extract of beluntas leaves with $25 \%$ in concentration is $0.516 \pm 0.408$, with $p=$ 0.023 or $p<0.05$, mouth rinsing using chlorhexidine 0,12\% shown that mean is $0.000 \pm 0.000$, with $p=0.020$ or $p<0.05$. mouth rinsing using Base formula material shown that mean is 0,833 \pm 0.408 , with $p=0,157$ or $p>0.05$. Analyze differences between groups to know the efectiveness of mouthwash treatment with Friedman test shown that $p$ value $=0.000$ or $p<0.05$. The conclusion is rinsing with ethanol extract of beluntas leaves with $12.5 \%$ and $25 \%$ in concentration and chlorhexidine 0,12\% can reduce halitosis significantly, but rinsing with base formula of mouthwash can not be overcome halitosis significantly. There are significant differences of effectiveness of mouthwash between groups to overcome halitosis.
\end{abstract}

Keywords: mouthwash, ethanol extract of beluntas leaves, halitosis, adolescent

\section{PENDAHULUAN}

Halitosis atau biasa disebut dengan bau mulut, oral malodor atau fetor ex oreadalah nafas tak sedap yang berasal dari udara yang dikeluarkan oleh seseorang lewat mulut dan merupakan suatu kondisi medis yang banyak dikeluhkan oleh masyarakat. Halitosis disebabkan oleh dua faktor, yaitu faktor ekstrinsik dan faktor intrinsik. Faktor ekstrinsik yang dapat menimbulkan halitosis adalah: tembakau, alkohol dan beberapa jenis makanan misalnya: 
durian, bawang merah, bawang putih dan bumbu-bumbu tertentu yang apabila dikonsumsi akan terabsorbsi ke sistem sirkulasi darah dan dilepaskan ke udara pernafasan atau ke dalam saliva dalam bentuk senyawa odoriferous yang mudah menguap yang menimbulkan bau tidak sedap. Faktor intrinsik penyebab halitosis terdiri dari dua bagian yaitu faktor lokal dan faktor sistemik. Menurut studi para ahli di Amerika, 90\% penyebab halitosis berasal dari faktor lokal dalam rongga mulut dan selebihnya berasal dari faktor sistemik ${ }^{1}$.

Halitosis dalam rongga mulut disebabkan oleh senyawa sulfur yang mudah menguap yang disebut dengan Volatile Sulphur Compounds (VSCs), yang terbentuk melalui reaksi dari bahan-bahan di dalam rongga mulut berupa protein yang berasal dari sisa makanan, sel-sel darah yang telah mati, sel-sel epitel yang terkelupas dari mukosa mulut dengan bakteribakteri anaerob seperti: Porphyromonas gingivalis, Solobacterium moorei, dan Treponema denticola. Bakteri-bakteri tersebut berkoloni di bagian posterior dorsum lidah, pada plak gigi di daerah subgingival, atau di dalam sulcus gingiva. Bakteri-bakteri tersebut dapat menyebabkan gingivitis serta keradangan pada jaringan periodontal yang disebut dengan periodontitis yang menimbulkan beberapa gejala salah satunya adalah halitosis ${ }^{1,2}$.

$\begin{array}{lcrr}\text { Halitosis } & \text { harus } & \text { dirawat } \\ \text { dengan baik } & \text { sesuai } & \text { dengan } \\ \text { penyebabnya } & \text { agar } & \text { tidak } \\ \text { menimbulkan } & \text { dampak } & \text { patologis } \\ \text { maupun } & \text { psikologis } & \text { pada }\end{array}$
penderitanya.Perawatan halitosis dapat dilakukan dengan berbagai cara menggunakan obat-obatan kimia maupun menggunakan ekstrak tumbuh-tumbuhan. Obat-obatan kimia yang digunakan secara luas dan dikenal umum oleh masyarakat adalah obat kumur yang mengandung klorheksidin dengan konsentrasi $0,12 \%$. Obat kumur ini merupakan antimikroba dengan spektrum luas yang efektif terhadap bakteri Gram positif maupun Gram negatif tetapi lebih efektif terhadap bakteri Gram positif $^{3}$.

Selain menggunakan obatobatan kimiawi, pengobatan halitosis dapat juga menggunakan ekstrak tumbuh-tumbuhan atau obat-obat tradisional yang telah banyak diteliti 
saat ini. Hasil penelitian, menyatakan bahwa untuk penghilang bau badan dan bau mulut dipergunakan daun combrang, daun imba, daun muda kenikir, bunga melati, daun sirih dan daun beluntas 4. Daun Beluntas (Pluchea indica.Less) adalah tumbuhan yang mudah dijumpai di Indonesia, umumnya tumbuh liar di daerah kering pada tanah yang keras dan berbatu, atau ditanam sebagai tanaman pagar ${ }^{5}$. Hasil penelitian menunjukkan bahwa ekstrak murni daun beluntas dapat menurunkan $70 \%$ jumlah bakteri dalam saliva ${ }^{6} .$. Penelitian ekstrak daun beluntas mempunyai aktivitas antibakteri terhadap Pseudomonas aeruginosa Multi Resistant dan Methicillin Resistant Staphylococcus aureus dengan konsentrasi daya hambat minimal adalah $20 \%$ dan $52 \%$. 7 . Hasil penelitian in vitro menunjukkan bahwa ekstrak etanol daun beluntas dengan konsentrasi $25 \%$ mempunyai daya hambat setara dengan klorheksidin 0,12\% untuk menghambat pertumbuhan bakteri Streptococcus mutans ${ }^{8}$. Hasil penelitian tersebut juga menunjukkan bahwa makin tinggi konsentrasi ekstrak, daya hambatnya makin besar terhadap pertumbuhan bakteri Streptococus mutans. Hasil penelitian ekstrak etanol daun beluntas efektif untuk menurunkan jumlah koloni Streptococcus sp. pada plak gigi ${ }^{9}$.Tujuan penelitian ini adalah untuk mengetahui efektivitas obat kumur ekstrak etanol daun beluntas (Pluchea indica.L.) untuk mengatasi halitosis pada remaja.

\section{METODE PENELITIAN}

Jenis penelitian ini adalah eksperimen dan rancangan completely randomized with preposttest control group design.

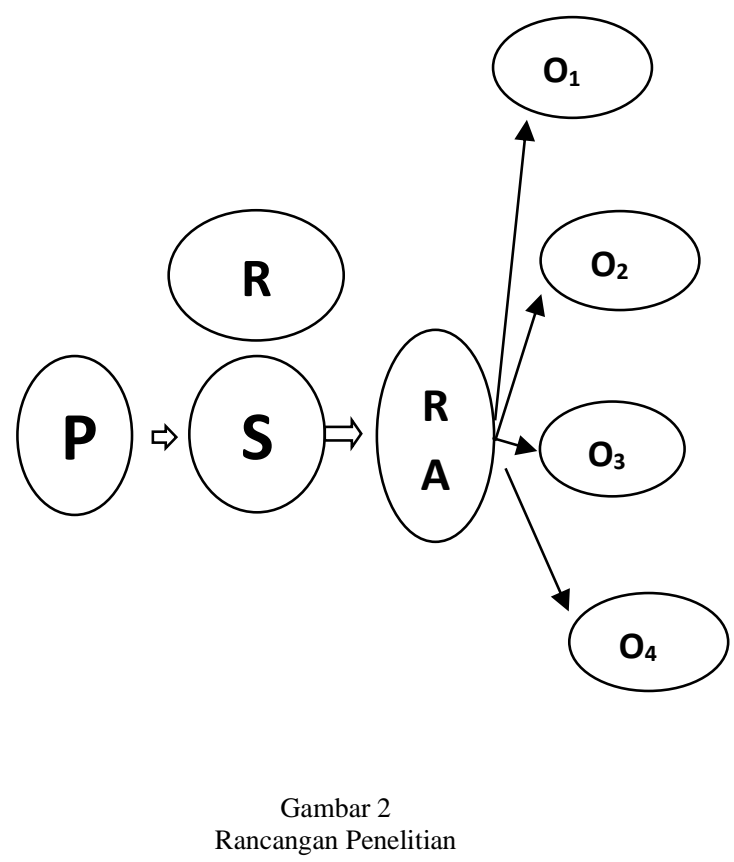

\section{Instrumen Penelitian}

Obat kumur ekstrak etanol daun beluntas dengan konsentrasi 12,5\%, 
dan $25 \%$, Klorheksidin $0,12 \%$ sebagai kontrol positif dan bahan/formula basis obat kumur sebagai kontrol negatif.Set alat diagnostik, Halimeter/breath checker Fitascan tipe HC-212SF, Blanko pencatatan hasil pengukuran tingkat VSCs, Gelas ukur 10 ml, Gelas kumur Populasi dalam penelitian ini adalah semua siswa SMP Budi Utama yang menderita halitosis dengan besar sampel ditentukan dengan menggunakan rumus besar sampel, sebagai berikut: $(\mathrm{t}-1)(\mathrm{r}-1) \geq 15$, dimana $t$ adalah jumlah perlakuan dan $r$ adalah jumlah pengulangan (replikasi) tiap kelompok perlakuan ${ }^{10}$ - Penelitian ini terdiri dari dua kelompok perlakuan dan dua kelompok kontrol, sehingga $\mathrm{t}=4$

Berdasarkan hasil perhitungan sampel didapatkan jumlah pengulangan yang dilakukan sebanyak enam kali untuk tiap kelompok sehingga jumlah sampel keseluruhan 24 orang sampel dengan tehnik accidental sampling

Prosedur penelitian mempersiapkan ekstrak kasar daun beluntas segar sebanyak 5000 gram, dihaluskan untuk mendapatkan bubuk beluntas (simplisia). Ekstrak etanol daun beluntas didapatkan dengan cara 500 gram simplisia dimaserasi (direndam) menggunakan lima liter pelarut etanol 96\% selama 48 jam. Setelah 48 jam dilakukan penyaringan menggunakan kertas Whatman No.2 untuk mendapatkan filtrat ${ }^{11}$. Selanjutnya dilakukan pengenceran ekstrak adalah: $12,5 \%, 25 \%$. Hasil penelitian tersebut juga menunjukkan bahwa makin tinggi konsentrasi ekstrak, daya hambatnya makin besar terhadap pertumbuhan bakteri Streptococus mutans, sehingga pada penelitian ini juga diteliti mulai konsentrasi yang lebih kecil yaitu 12,5 sebagai kelipatannya ${ }^{12}$.

Cara pengumpulan data dengan mengidentifikasi subyek penelitian memenuhi kriteria inklusi sampel dibagi menjadi empat kelompok yaitu dua kelompok perlakuan dan dua kelompok kontrol, masing-masing terdiri dari enam. Hari pertama responden dari kelompok perlakuan maupun kelompok kontrol diukur tingkat VSCs menggunakan breath checker Fitscan model HC-212SF (halimeter). Responden diinstruksikan untuk melakukan sikat gigi yang benar, 30 menit kemudian berkumur-kumur masing-masing 
menggunakan ekstrak daun beluntas dengan konsentrasi 12,5\%, 25\%, klorheksidin $\quad 0,12 \%$ dan formula bahan basis obat kumur sebanyak 10 ml selama 60 detik. Kumur-kumur dilanjutkan di rumah sesuai dengan prosedur yang telah dilakukan yaitu responden melakukan sikat gigi yang benar, 30 menit kemudian berkumurkumur masing-masing menggunakan ekstrak daun beluntas dengan konsentrasi 12,5\%, 25\%, klorheksidin $0,12 \%$ dan formula bahan basis bahan basis obat, kumur sebanyak $10 \mathrm{ml}$ selama 60 detik setiap kali berkumur. Pelaksanaan kegiatan di rumah diawasi orang tua, dan dicatat waktu kegiatan pada kartu kontrol dan ditandatangani orang tua. Kegiatan tersebut diulang kembali, selama 7 hari berturut-turut dan pengukuran tingkat VSCs dilakukan pada hari kedelapan. Data yang terkumpul selanjutnya dianalisis secara statistik dengan uji deskriptif dengan uji Wilcoxon dan Uji komparatif antar kelompok data menggunakan uji Friedman 13.

\section{HASIL}

Analisis efek perlakuan diuji berdasarkan score Halitosis antara sebelum dengan sesudah diberikan perlakuan pada hari kedelapan. Hasil analisis kemaknaan antar kelompok dengan uji Friedman sedangkan untuk mengetahui efektivitas kasiat obat kumur sebelum dan sesudah berkumur dilakukan dengan uji Wilcoxon, karena data penelitian non parametrik.

Tabel 3. Rerata Halitosis Sebelum dan Sesudah Berkumur dengan Obat Kumur Ekstrak Etanol Daun Beluntas 12,5\% untuk Mengatasi Halitosis pada Remaja

\begin{tabular}{|c|c|c|c|c|c|c|}
\hline \multirow{3}{*}{\multicolumn{2}{|c|}{$\begin{array}{l}\text { Vari } \\
\text { abel }\end{array}$}} & & $\begin{array}{l}\text { mur } \\
\text { un I } \\
12\end{array}$ & $\begin{array}{l}\text { Ekst } \\
\text { elun } \\
5 \%\end{array}$ & & \multirow{3}{*}{$\mathrm{p}$} \\
\hline & & \multicolumn{2}{|c|}{$\begin{array}{c}\text { Sebelu } \\
\text { m }\end{array}$} & Ses & dah & \\
\hline & & $\begin{array}{c}\text { M } \\
\text { ea } \\
\mathrm{n}\end{array}$ & $\begin{array}{l}\text { S } \\
\text { B }\end{array}$ & $\begin{array}{c}\mathrm{M} \\
\text { ea } \\
\mathrm{n}\end{array}$ & SB & \\
\hline $\begin{array}{l}\text { Halit } \\
\text { osis }\end{array}$ & 0 & $\begin{array}{c}1,3 \\
3\end{array}$ & $\begin{array}{l}0, \\
52\end{array}$ & $\begin{array}{l}0,1 \\
67\end{array}$ & $\begin{array}{l}0,4 \\
08\end{array}$ & $\begin{array}{l}0,0 \\
38\end{array}$ \\
\hline
\end{tabular}

Tabel 3 menunjukkan bahwa rerata halitosis hari pertama adalah, $1,33 \pm 0,52$ sedangkan rerata hari kedelapan adalah $0,167 \pm 0,408$. Analisis kemaknaan dengan uji Wilcoxon menunjukkan nilai $\mathrm{p}=$ 0,038 atau $p<0,05$. Hal ini berarti bahwa ada perbedaan score halitosis secara bermakna sebelum dan sesudah berkumur pada kelompok 
yang kumur-kumur dengan ekstrak etanol daun beluntas $12,5 \%$.

Tabel 4. Rerata Halitosis Sebelum dan Sesudah Berkumur dengan Ekstrak Etanol Daun Beluntas 25\% untuk Mengatasi Halitosis pada Remaja

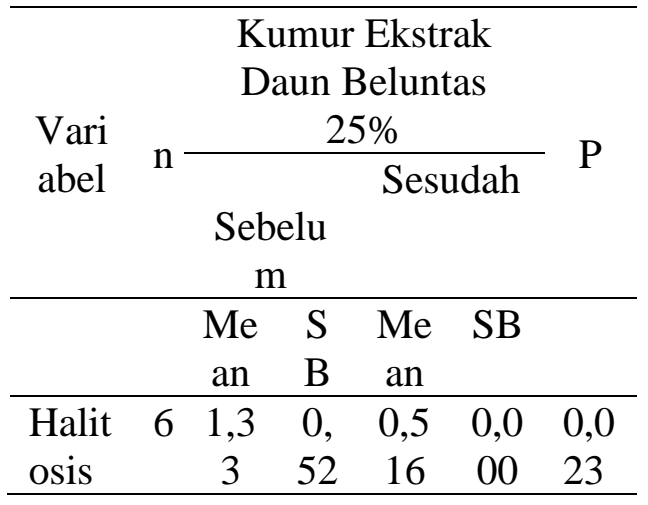

Tabel 4 menunjukkan bahwa rerata halitosis hari pertama adalah, $1,33 \pm 0,52$ sedangkan rerata hari kedelapan adalah $0,516 \pm 0,408$. Analisis kemaknaan dengan uji Wilcoxon nilai $\mathrm{p}=0,023$ atau $\mathrm{p}<$ 0,05 .

Tabel 5. Rerata Halitosis Sebelum dan Sesudah Berkumur dengan Obat Kumur Klorheksidin 0,12\% untuk Mengatasi Halitosis pada Remaja Kumur Klorheksidin

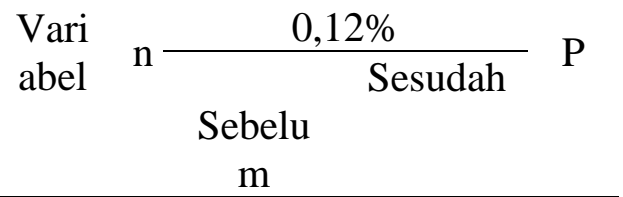

\begin{tabular}{|c|c|c|c|c|c|}
\hline & $\begin{array}{c}\mathrm{M} \\
\text { ea } \\
\mathrm{n}\end{array}$ & SB & $\begin{array}{c}\mathrm{M} \\
\text { ea } \\
\mathrm{n}\end{array}$ & SB & \\
\hline Halit & 1,1 & 0,4 & 0,0 & 0,0 & 0,0 \\
\hline osis & 66 & 08 & 00 & 00 & 20 \\
\hline
\end{tabular}

Tabel 5 menunjukkan bahwa rerata halitosis hari pertama adalah, $1,166 \pm 0,408$ sedangkan rerata hari kedelapan adalah $0,000 \pm 0,000$. Analisis kemaknaan dengan uji Wilcoxon nilai $\mathrm{p}=0,020$ atau $\mathrm{p}<$ 0,05 .

Tabel 6. Rerata Halitosis Sebelum dan Sesudah Berkumur dengan Formula Bahan Basis Obat Kumur untuk Mengatasi Halitosis pada Remaja

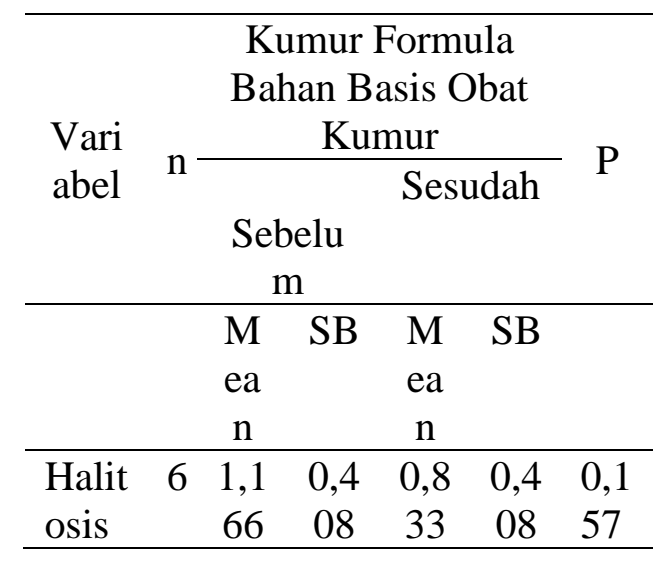

Tabel 6 menunjukkan bahwa rerata halitosis hari pertama adalah, $1,166 \pm 0,408$ sedangkan rerata hari kedelapan adalah 0,833 $\pm 0,408$. Analisis kemaknaan dengan uji 
Wilcoxon nilai $\mathrm{p}=0,157$ atau $\mathrm{p}>$ 0,05 .

Tabel 7. Rerata Halitosis antar

Kelompok Perlakuan untuk

Mengetahui Perbedaan Efektivitas

obat Kumur untuk Mengatasi

Halitosis

\begin{tabular}{|c|c|c|c|c|}
\hline \multirow{2}{*}{$\begin{array}{c}\text { Kelomp } \\
\text { ok } \\
\text { Subjek }\end{array}$} & \multirow{2}{*}{$\mathrm{N}$} & \multicolumn{2}{|c|}{$\begin{array}{c}\text { Mean Rank } \\
\text { Halitosis }\end{array}$} & \multirow{2}{*}{$\mathrm{p}$} \\
\hline & & $\begin{array}{l}\text { Sebe } \\
\text { lum }\end{array}$ & $\begin{array}{c}\text { Sesu } \\
\text { dah }\end{array}$ & \\
\hline $\begin{array}{l}\text { Formula } \\
\text { Bahan } \\
\text { Basis } \\
\text { Obat } \\
\text { Kumur }\end{array}$ & 6 & 5,92 & 4,83 & \multirow{4}{*}{0,000} \\
\hline $\begin{array}{l}\text { Khlorhe } \\
\text { ksidin } \\
0,12 \%\end{array}$ & 6 & 6,00 & 2,00 & \\
\hline $\begin{array}{l}\text { Ekstrak } \\
\text { Etanol } \\
\text { Daun } \\
\text { Beluntas } \\
12,5 \%\end{array}$ & 6 & 6,33 & 2,88 & \\
\hline $\begin{array}{l}\text { Ekstrak } \\
\text { Etanol } \\
\text { Daun } \\
\text { Beluntas } \\
25 \%\end{array}$ & 6 & 6,33 & 2,00 & \\
\hline
\end{tabular}

Tabel 7 menunjukkan hasil ranking tentang penurunan tingkat halitosis sebelum dan sesudah berkumur dengan uji Friedman yaitu penurunan terbesar pada kelompok yang berkumur dengan ekstrak etanol daun beluntas $25 \%$ selanjutnya pada kelompok berkumur dengan Klorheksidin $0,12 \%$ kemudian pada kelompok berkumur dengan ekstrak etanol daun beluntas $12,5 \%$ dan terakhir pada kelompok formula bahan basis obat. Nilai $p=0,000$ atau $\mathrm{p}<0,05$, hal ini berarti bahwa ada perbedaan yang bermakna antar kelompok perlakuan untuk mengatasi halitosis.

\section{PEMBAHASAN}

Hasil analis berkumur dengan ekstrak daun beluntas $12,5 \%$ didapatkan rerata halitosis hari pertama adalah $1,333 \pm 0516$, sedangkan rerata hari ke delapan adalah $0,166 \pm 0,408$. Analisis kemaknaan dengan uji Wilcoxon nilai $\mathrm{p}=0,038$ atau $\mathrm{p}<0,05$. Hal ini berarti bahwa ada perbedaan score halitosis secara bermakna sebelum dan sesudah berkumur pada kelompok yang kumur-kumur dengan ekstrak etanol daun beluntas 12,5\%. Sama halnya pada kelompok berkumur dengan ekstrak daun beluntas $25 \%$ yaitu rerata halitosis hari pertama adalah, 1,33 $\pm 0,52$ sedangkan rerata hari kedelapan adalah 0,516 $\pm 0,408$. Analisis kemaknaan dengan uji Wilcoxon nilai $\mathrm{p}=0,023$ atau $\mathrm{p}<0,05$ . Hal ini berarti bahwa ada perbedaan score halitosis secara bermakna sebelum dan sesudah berkumur pada kelompok yang kumur-kumur dengan ekstrak daun beluntas 25\%. Hasil penelitian ini mungkin disebabkan oleh senyawa bioaktif yang terdapat 
dalam daun beluntas merupakan senyawa metabolit sekunder. Kandungan kimia dalam daun beluntas adalah: alkaloid,steroid, flavonoid, tannin, fenol. Steroid sebagai salah satu metabolit sekunder yang terdapat pada ekstrak daun beluntas, merupakan derivat senyawa terpen yaitu triterpenoid mempunyai aktivitas antibakteri, antiparasit, antiinflamasi, antijamur, kardiotonik dan efek anabolic ${ }^{14,15,16,17}$. Penelitian yang lain menunjukkan bahwa senyawa flavonoid mempunyai aktivitas antimikroba melalui beberapa mekanisme yaitu: 1) menghambat sintesis dinding sel bakteri; 2) menyebabkan protein leakage akibatnya terjadi kebocoran dinding sel bakteri; 3) menghambat sintesis protein bakteri; dan 4) kemungkinan mengintervensi fungsi DNA sel bakteri ${ }^{18,19}$. Halitosis dalam rongga mulut disebabkan oleh senyawa sulfur disebut dengan Volatile Sulphur Compounds (VSCs), yang mudah menguap, yang terbentuk melalui degradasi protein yang diikuti dengan pemecahan asam-asam amino tertentu yaitu: methionine, cysteine, tryptophan, dan lysine yang berasal dari sisa makanan, sel-sel darah yang telah mati, sel-sel epitel yang terkelupas dari mukosa mulut oleh bakteri-bakteri anaerob Gram negatif. Perawatan halitosis didasarkan atas asumsi bahwa halitosis disebabkan oleh mikroorganisme dalam rongga mulut yang memproduksi senyawa sulfur yang menyengat hidung dan perawatan utama yang dilakukan adalah mengurangi jumlah mikroorganisme dengan cara mekanis maupun kimiawi ${ }^{20}$. Senyawa bioaktif daun beluntas memiliki aktivitas antibakteri dengan cara membentuk kompleks dengan prolin yaitu sejenis protein pada dinding sel bakteri, menyebabkan protein leakage, terjadi kerusakan dinding sel bakteri sehingga menyebabkan kematian sel bakteri ${ }^{21,22,19}$. Ekstrak murni daun beluntas dapat menurunkan $70 \%$ jumlah bakteri dalam saliva sesuai dengan hasil penelitian ${ }^{6}$ Sesuai dengan hasil penelitian menunjukkan bahwa ekstrak daun beluntas mempunyai aktivitas antibakteri terhadap Pseudomonas aeruginosa Multi Resistant dan Methicillin Resistant Staphylococcus aureus dengan konsentrasi daya hambat minimal adalah $20 \%$ dan $52 \%{ }^{7}$ Hasil 
penelitian tersebut juga menunjukkan bahwa makin tinggi konsentrasi ekstrak, daya hambatnya makin besar terhadap pertumbuhan bakteri Streptococus mutansntas 25\%. Hasil ini menunjukkan bahwa ekstrak etanol daun beluntas $12,5 \%$ dan $25 \%$ diduga mempunyai khasiat anti bakteri sehingga sebagian masyarakat mempunyai kebiasaan untuk berkumur-kumur menggunakan air rebusan daun beluntas untuk menghilangkan bau mulut atau halitosis.

Hasil analisis pada kelompok yang berkumur dengan Khlorheksidin $0,12 \%$ menunjukkan bahwa rerata halitosis hari pertama adalah, $1,166 \pm 0,408$ sedangkan rerata hari kedelapan adalah $0,000 \pm 0,000$. Analisis kemaknaan dengan uji Wilcoxon nilai $\mathrm{p}=0,020$ atau $\mathrm{p}<$ 0,05 . Hal ini berarti bahwa ada perbedaan score halitosis secara bermakna sebelum dan sesuah berkumur pada kelompok yang kumur-kumur dengan khlorhexidin $0,12 \%$. Hasil penelitian ini disebabkan karena kemampuannya untuk mengurangi bakteri baik aerobic maupun anaerobic mencapai $54 \%-97 \%$. Obat kumur ini efektif terhadap bakteri Gram positif dan negatif meskipun terhadap beberapa bakteri Gram negatif kurang efektif ${ }^{3}$. Mekanisme kerja klorheksidin dahulu diduga bersifat bakterisid dengan cara menginaktifkan ATPase bakteri namun ada pendapat lain yang mengatakan bahwa klorheksidin bersifat bakterisid kemudian menjadi bakteriostatik dengan cara merusak dinding sel bakteri, menghambat sistem enzimatik bakteri, mengeluarkan lipopolisakarida bakteri sehingga menyebabkan kematian sel bakteri ${ }^{23,24}$. Dengan demikian obat kumur Klorheksidin $0,12 \%$ tidak diragukan lagi sebagai obat kumur yang dapat mengatasi terjadinya halitosis.

Berdasarkan hasil analisis pada kelompok yang berkumur dengan basis obat kumur yaitu rerata halitosis hari pertama adalah, $1,166 \pm 0,408$ sedangkan rerata hari kedelapan adalah $0,833 \pm 0,408$. Analisis kemaknaan uji Wilcoxon nilai $\mathrm{p}=0,157$ atau $\mathrm{p}>0,05$. Hal ini berarti bahwa tidak ada perbedaan score halitosis secara bermakna sebelum dan sesudah berkumur pada kelompok berkumur dengan formula bahan basis obat kumur. Hasil 
penelitian menunjukkan bahwa formula basis obat kumut tidak bermakna atau tidak berkasiat untuk mengatasi halitosis karen formulasi obat basis komposisinya hanya mengandung oleium olive, aquadest dan menthol sebagai bahan penyegar saja.

Hasil ranking tentang perbedaan penurunan tingkat halitosis sebelum dan sesudah berkumur dengan uji Friedman, terbesar pada kelompok yang berkumur dengan ekstrak etanol daun beluntas $25 \%$ selanjutnya pada kelompok berkumur dengan Khlorheksidin $\quad 0,12 \%$ kemudian pada kelompok berkumur dengan ekstrak etanol daun beluntas $12,5 \%$ dan terakhir pada kelompok formula bahan basis obat. Besar nilai $\mathrm{p}=0,000$ atau $\mathrm{p}<0,05$ hal ini berarti bahwa ada perbedaan yang bermakna antar kelompok perlakuan untuk mengatasi halitosis. Perbedaan hasil efektivitas obat kumur dalam penelitian ini sesuai dengani hasil penelitian in vitro menunjukkan bahwa ekstrak etanol daun beluntas dengan konsentrasi $25 \%$ mempunyai daya hambat setara dengan klorheksidin $0,12 \%$ untuk menghambat pertumbuhan bakteri Streptococcus mutans. Lebih lanjut dijelaskan bahwa makin tinggi konsentrasi ekstrak, daya hambatnya makin besar terhadap pertumbuhan bakteri Streptococus mutans ${ }^{8}$. Daun beluntas berbau khas aromatik dan rasanya getir, banyak mengandung zat berkhasiat yang sering digunakan untuk menghilangkan bau badan, bau mulut, mengatasi kurang nafsu makan, mengatasi gangguan pencernaan pada anak ${ }^{5}$. Sama halnya dengan obat Khlorheksidin diindikasikan sebagai obat kumur untuk mengurangi jumlah bakteri dalam rongga mulut pada pasien yang menderita gingivitis, periodontitis, trauma pada gigi, kista rongga mulut dan setelah pencabutan gigi. Obat kumur ini digunakan dua kali sehari 23,25 .

\section{SIMPULAN}

Kelompok berkumur dengan obat kumur ekstrak etanol daun beluntas $12,5 \%$ penurunan rerata halitosis sebelum berkumur 1,33 menjadi 0,16 setelah berkumur, pada konsentrasi ekstrak etanol daun beluntas $25 \%$ penurunan rerata halitosis sebelum berkumur 1,33 menjadi 0,156 setelah 
berkumur. Dengan uji Wilcoxon kedua kelompok perlakukan ini diduga efektif mengatasi halitosis.

Pada kelompok yang berkumur dengan obat kumur klorheksidin $\quad 0,12 \%$ penurunan rerata halitosis dari 1,166 menjadi 0,000 setelah berkumur. Dengan uji Wilcoxon obat kumur ini memang tidak diragukan lagi dan efektif sebagai obat kumur untuk mengatasi halitosis karena sifatnya anti bakteri dan bakterisid.

Kelompok berkumur dengan formulasi basis obat kumur dari 1,166 menjadi 0,833 setelah berkumur. dengan uji wilcoxon obat ini tidak efektif digunakan untuk mengatasi halitosis karena komposisi formula ini hanya minyak, aquades dan bahan perasa saja.

Terjadi perbedaan penurunan tingkat halitosis secara bermakna antar kelompok perlakuan sebelum dan sesudah berkumur sesuai dengan mean rank dengan uji Friedman, terbesar pada kelompok yang berkumur dengan ekstrak etanol daun beluntas $25 \%$ selanjutnya pada kelompok berkumur dengan Klorheksidin
0,12\% kemudian pada kelompok berkumur dengan ekstrak etanol daun beluntas $12,5 \%$ dan terakhir pada kelompok formula bahan basis obat.

\section{SARAN}

Perlu dilakukan penelitian lebih lanjut tentang pengujian obat kumur ekstrak daun beluntas terhadap khasiat dalam mengatasi halitosis. Formulasi obat kumur sebaiknya diturunkan konsentrasinya agar rasanya lebih nyaman untuk berkumur dan ditambahkan dengan bahan perasa yang lain sehingga obat kumur menjadi lebih menarik.

\section{DAFTAR PUSTAKA}

1 Rosenberg, M. 2002. The Science of Bad Breath. Sci. Am. Apr.; 286 (4): 72-79

2 Clarck,B., Harasthy,V.I., Scientist Find Bug Responsible for Bad Breath. Article. (Serial Online), (cited, 2010, November 4), Available from: http://ukreuters.com/artcle/idU KTON77980320080407

3 Shahani, M.N., Reddy, V.V.S. 2011. Comparison of Antimicrobial Substantivity of Root Canal Irrigants in Instrumented RootCanals up to 72 Hours: An Invitro Study. Journal of Indian Soc. Pedod. Prev. Dent. 29: 28-33

4 Suriawiria, U, 2000, Obat Mujarab dari Pekarangan 
Rumah.Jakarta: Papas Sinar Sinanti. p. 29

5 Dalimartha, S.1999, Atlas Tumbuhan Obat Indonesia, Jilid I. J akarta:TrubusAgriwidya. p. $18-21$

6 Nahak,M.M.,

Tedjasulaksana,R., dan Dharmawati, IG.G.A. 2007.Khasiat Ekstrak Daun Beluntas untuk Menurunkan Jumlah Bakteri pada Saliva. Interdental Jurnal Kedokteran gigi, Denpasar. 5(3): 139-142

7 Sulistyaningsih, Rr. 2009. Potensi Daun Beluntas (Pluchea indica Less) Sebagai Inhibitor Terhadap Pseudomonas aeruginosa Multi Resistant dan Methicilline Resistant staphylococcus aureus. Laporan Penelitian Mandiri. Fakultas Farmasi Univ. Padjadjaran Bandung. p. 34-35

8 Nahak, M.M. 2012. Ekstrak Etanol Daun Beluntas (Pluchea indica. L.) dapat Menghambat Pertumbuhan Bakteri Streptococcus mutans. Laporan Disertasi. Program Pasca Sarjana Universitas Udayana, Denpasar.

9 Nahak, M.M., Tedjasulaksana, R., Sumerti, N.N., 2015. Efektivitas Ekstrak Etanol Daun Beluntas untuk Menurunkan Jumlah Koloni Streptococcus sp. Pada Plak Gigi. Jurnal Skala Husada, Denpasar.12(1): 56-64

10 Frederer, W.T. 1977. Experimental Design Theory and Application. $3^{\text {rd }}$ Edition. New Delhi, Bombay Calcuta. Oxford and IBH Publishing.Co. p. 544
11 Pasaribu, S.P. 2009. Uji Bioaktivitas Metabolit Sekunder dari Daun Tumbuhan Babadotan (Ageratum conyzoides L.). Jurnal Kimia Mulawarman. 6(2): 1-7

12 Arief. 2000. Ilmu Meracik Obat. Teori dan Praktek. Yogyakarta: Gadjahmada University Press. p. 25

13 Sunyoto, D, 2012, Statistik Non Parametrik untuk Kesehatan.Yogyakarta:Nuha Medika

14 Islam, A.K., Ali, M.A., Sayeed, A., Salam, S.M., Islam, A., Rahman, M., Khan, G.R., Khatun, S. 2003. An Antimicrobial Terpenoid from Caesalpinia pulcerrima Swartz: Its Characterization, Antimcrobial and Cytotoxic Activities. Asian J Plant Sci. 2: 17-24

15 Prabuseenivasan, S., Jayakumar, M., Ignacimuthu, S. 2006. In vitro Antibacterial Activity of Some Plant Essential Oils. BMC Complement. Altern. Med. 6:39

16 Praptiwi, Chairul, Harapini, M. 2006. Uji Efektivitas Ekstrak Etanol Buah Makasar (Brucea javanica L.Merr.) terhadap Plasmodium berghei Secara invivo pada Mencit. Laporan Penelitian. Bidang Botani, Puslit Biologi-LIPI, Bogor. p. 1-6

17 John, A.J., Kanurakran, V.P., George, V. 2007. Antibacterial Activity of Neolitsea foliosa (Nees) Gamlbe var. caesia (Meisner). J.Essent.Oil. Res. 19:498-500

18 Hussain, A., Wahab, S., Zarin, I., Sarfaraj Hussain, M.D. 
2010. Antibacterial Activity of the Leaves of Cocconia indica (W. and A) Wof India. Advances in Biological Research. 4(5): 241-248

19 Mohamed, S.S.H., Hansi, P.D., Thirumurugan, K. 2010. Antimicrobial Activity and Phytochemical Analysis of Selected Indian Folk Medicinal Plants. International Journal of Pharma Sciences and Research (IJPSR). 1(10): 430-434

20 Rosenberg, M., Amit, A. 2009. Home Care and Treatment of Bad Breath. Article. (Serial Online) (Cited 2011 Sept 11). Available from:

http://Smellwell.com/treatmentof-bad-breath

21 Machado, T.B., Pinto, A.V., Pinto, M.C.F.R., Leal, I.C.R., Silva, M.G., Amaral, A.C.F., Kuster, R.M., Netto-dos Santoz, K.R. 2003. In vitro Activity of Brazilian Medicinal Plants, Naturally Occuring Naphtoquinones and Their Analogues Against Methicilline Resistant Staphyloccoccus aureus. International Journal of Antimicrobial Agents. 21: 279284

22 Braga, L.C., Shupp, J.W., Cummings, C., Jett, M.,
Takahashi, J.A., Carmo, L.S., Chartone-Souza, E., Nasclmento, A.M.A. 2005. Pomegranate Extract Inhibits Staphylococcus aureus Growth and Subsequent Enterotoxin Production. Journal of Ethnopharmacology. 96 : 335339

23 Kuyyakanond, T., Quenel, L.B. 1992. The Mechanism of Action of Chlorhexidine. FEMS Microbiol Lett. 79(1-3): 211215

24 Mandel, I.D. 1994. Antimicrobial Mouth Rinses: Overview \& Update. J Am Dent Assoc. 125(25): 2S -10S

25 Kolahi, J., Soolati, A. 2006. Rinsing with Chlorhexidine Gluconate Solution after Brushing and Flossing Teeth: a Systematic Review of Effectiveness. Quintessence Int. 37(8): 605-12 